\title{
ARTICLE Comparison of Meat Quality Characteristics of Wet- and Dry-aging Pork Belly and Shoulder Blade
}

\author{
Young-Hwa Hwang ${ }^{1,{ }^{\dagger}}$, Nahar Sabikun ${ }^{2,{ }^{\dagger}}$, Ishamri Ismail ${ }^{2}$, and Seon-Tea Joo ${ }^{1,2,{ }^{*}}$ \\ ${ }^{1}$ Institute of Agriculture \& Life Science, Gyeongsang National University, Jinju 52828, \\ Korea \\ ${ }^{2}$ Division of Applied Life Science (BK21Plus), Gyeongsang National University, Jinju \\ 52828, Korea
}

IOPEN ACCESS

Received July 11, 2018
Revised July 31, 2018
Accepted July 31, 2018

*Corresponding author : Seon-Tea Joo
Division of Applied Life Science (BK21Plus),
Gyeongsang National University, Jinju 52828,
Korea
Tel: +82-55-772-1943
Fax: +82-55-772-1949
E-mail: stjoo@gnu.ac.kr
† The first two authors have equal contribution.

Abstract The physicochemical characteristics and oxidative stability of wet-aged and dryaged pork cuts were investigated at different aging periods (1, 7, 14 and $21 \mathrm{~d}$ ). Samples were assigned into four groups in terms of shoulder blade-wet aging (SW), shoulder bladedry aging (SD), belly-wet aging (BW), and belly-dry aging (BD). SD showed significantly higher $\mathrm{pH}$ at $21 \mathrm{~d}$ of aging than the other samples. Wet-aged cuts had significantly higher released water $(\mathrm{RW}) \%$, lightness $\left(\mathrm{L}^{*}\right)$ and shear force compared to the dry-aged meats. Sodium dodecyl sulfate-polyacrylamide gel electrophoresis (SDS-PAGE) analysis showed greater degradation of proteins for dry-aged cuts than the wet-aged cuts. At the end of aging, wet-aged cuts showed significantly lower thiobarbituric acid-reactive substances (TBARS) value than the dry-aged samples, indicating higher oxidative stability for wet-aged pork cuts. However, dry-aging led to higher degradation of proteins resulting in increased waterholding capacity (WHC) and decreased shear force value.

Keywords dry-aged pork, pork aging, dry aging, wet aging, pork quality

\section{Introduction}

Pork is widely available and an important meat protein source. The consumer demand for nutritive and high quality fresh meat cuts has always been important (Joo et al., 2013). Fresh meats often are aged to enhance the characteristics of palatability related to various retail and wholesale cuts. Postmortem aging improves meat palatability by enhancing tenderness, juiciness, and/or flavor perception owing to structural breakdown of muscles by endogenous proteases (Kim et al., 2016). The traditional process of aging is dry-aging due to its positive effects on palatability particularly flavor attributes, and has been practiced by local meat processors to attract customers (Kim et al., 2017). In addition, dry aging (storing without protective packing) is the most common form of postmortem aging to improve tenderness and flavor perception of meat products for a longer period of time (Smith et al., 2008). But,

(C) Korean Society for Food Science of Animal Resources. This is an open access article distributed under the terms of the Creative Commons Attribution Non-Commercial License (http://creativecommons.org/licences/by-nc/3.0) which permits unrestricted non-commercial use, distribution, and reproduction in any medium, provided the original work is properly cited. 
several researchers have provided conflicting information that there are no detectable impacts of dry-aging on palatability components for beef (Dikeman et al., 2013; Laster et al., 2008; Smith et al., 2008).

It is accepted that dry-aging has some drawbacks such as dry-aged cuts lose more weight owing to loss of water, they suffer from a high amount of shrinkage, have a greater amount of trim loss, requires a more time and space, which makes it expensive (Smit et al., 2008; Stenström et al., 2014). Therefore, dry-aged meats are used by some high end-restaurants or special outlets to meet the demand of consumers who prefer this unique product (Smith et al., 2008). By contrast, wet aging (aged in a vacuum packet) loses less weight, is more juicy and tender, little or no cooler shrinkage, is relatively low cost, and is more common and quicker entry to the market (Adegoke and Falade, 2005). However, the information about quality traits of dry-aged and wet-aged pork cuts is limited. The objective of this study was to investigate meat quality traits and oxidative stability of wet aging and dry aging pork cuts (shoulder blade and belly) at different aging periods of 1, 7, 14 and $21 \mathrm{~d}$.

\section{Materials and Methods}

\section{Sample preparation}

Ten shoulder blade and belly cuts from 5 pork carcasses were sampled at postmortem $24 \mathrm{~h}$ at a commercial meat plant, and they were assigned into four groups in terms of shoulder blade-wet aging (SW), shoulder blade-dry aging (SD), belly-wet aging (BW), and belly-dry aging (BD). All samples were transferred for wet aging and dry aging for $21 \mathrm{~d}$, for subsequent analysis on day $1,7,14$ and 21 .

\section{Muscle pH}

The $\mathrm{pH}$ of the pork muscle was measured using a portable $\mathrm{pH}$ meter (MP 230, Mettler Toledo, Switzerland). Approximately $3.0 \mathrm{~g}$ of meat sample was mixed with $27 \mathrm{~mL}$ deionized water and then homogenized (IKA T25, ULTRA-

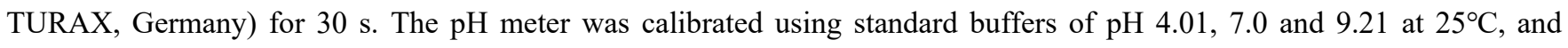
measured the $\mathrm{pH}$ of the sample.

\section{Water-holding capacity}

Water-holding capacity (WHC) of all samples was measured by released water (RW) method of Joo (2018). Approximately $3.0 \mathrm{~g}$ of intact meat was weighed and placed on a previous desiccated and weighed filter-paper (Whatman No. 1 of $11 \mathrm{~cm}$ of diameter) with two thin plastic films. After weighing them, the filter-paper and plastic film with meat sample were placed between plexiglass plates, then a load of $2.5 \mathrm{~kg}$ was applied for $5 \mathrm{~min}$. After accurately removing the compressed meat sample, the damp filter-paper and two plastic films were rapidly weighed. The percentage of RW \% was calculated as follows;

$$
\text { RW } \%=\frac{(\text { Damp filter-paper and plastic films weight })-(\text { filter-paper and plastic films weight })}{\text { Meat sample weight }} \times 100
$$

\section{Color measurements}

Color measurements of the different pork cuts were determined using a colorimeter (Minolta CR -300, Minolta Co., Japan) that was standardized with a white plate $(\mathrm{Y}=93.5, \mathrm{X}=0.3132, \mathrm{y}=0.3198)$ before measuring. The color parameters were expressed as $\mathrm{L}^{*}$ (lightness), $\mathrm{a}^{*}$ (redness), $\mathrm{b}^{*}$ (yellowness), polar-coordinate Chroma $\left(\mathrm{C}^{*}\right)$, and hue angle $\left(\mathrm{h}^{\circ}\right)$. 


\section{Warner -Bratzler shear force}

Warner-Bartzler shear force (WBSF) values were measured using an Instron Universal testing Machine (Model 4400, Instron Co., USA) with a V shaped shear blade. Samples (1.0 cm-diameter cores obtained from muscle) were cooked to an internal temperature of $70^{\circ} \mathrm{C}$ for $30 \mathrm{~min}$.

\section{SDS-PAGE analysis}

Sodium dodecyl sulfate-polyacrylamide gel electrophoresis (SDS-PAGE) analysis of dry-aged and wet-aged pork cuts was carried at 7, 14, and $21 \mathrm{~d}$ following a modified method of Laemmli (1970). The sample (300 mg) was homogenized with 27 $\mathrm{mL}$ of sample buffer containing $125 \mathrm{mM}$ Tris- $\mathrm{HCl}$ (pH 6.8), $200 \mathrm{mM}$ dithiothreirol (DTT), 4\% SDS, 20\% glycerol, $0.02 \%$ bromophenol blue. Then the homogenized sample was centrifuged at $3,000 \times \mathrm{g}$ for $15 \mathrm{~min}$ at $4^{\circ} \mathrm{C}$. The supernatant was incubated at $95^{\circ} \mathrm{C}$ for $5 \mathrm{~min}$ in a water bath to dissociate the proteins, and then allowed to cool in cold water. For electrophoresis, denatured samples were separated (20 $\mu \mathrm{g}$ protein/lane) onto a $12.5 \%$ polyacrylamide separating gel of 1.5 $\mathrm{mm}$ thickness $(12.5 \mathrm{~mL}$ of acrylamide solution containing $30 \%$ acrylamide and $0.8 \%$ bisacrylamide, $7.5 \mathrm{~mL}$ of $1.5 \mathrm{M}$ Tris$\mathrm{HCl} \mathrm{pH} \mathrm{8.8,} 0.3 \mathrm{~mL}$ of $10 \% \mathrm{SDS}, 9.6 \mathrm{~mL} \mathrm{ddH}_{2} \mathrm{O}, 150 \mu \mathrm{L}$ of $10 \%$ ammonium persulphate, $10 \mu \mathrm{L}$ TEMED) and stacking gel ( $0.88 \mathrm{~mL}$ of acrylamide solution, $1.66 \mathrm{~mL}$ of $1.5 \mathrm{M}$ Tris- $\mathrm{HCl} \mathrm{pH}$ 8.8, $66 \mu \mathrm{L}$ of $10 \%$ SDS, $4.06 \mathrm{~mL}$ of $\mathrm{H}_{2} \mathrm{O}, 33.4 \mu \mathrm{L}$ of $10 \%$ ammonium persulphate, $3.3 \mu \mathrm{L}$ TEMED). Broad range molecular weight standards (5 to $250 \mathrm{kDa}$ ) were run on each gel to determine protein molecular weights and to account for gel-to-gel variations. Gels were run at a constant voltage (20 mA for $240 \mathrm{~min}$ ) using a mini-vertical gel electrophoresis unit SE 260 (Amersham Biosciences, USA). Following the run, the PAGE gel was stained with Coomassie brilliant blue R-250 staining solution (0.025\% Coomassie brilliant blue R-250, 40\% methanol, 7\% acetic acid), and destained with solution I (40\% methanol and 7\% acetic acid) for 30 min and solution II (7\% acetic acid and 5\% methanol) until a clear background was obtained. Images of the gels were captured on a Hoefer UV-vis light (Hoefer ${ }^{\circledR}$ MacroVue UVis-20, Holliston, USA) and analyzed using ImageJ software (Version 1.52a, National Institute of Health, USA).

\section{Thiobarbituric acid -reactive substance (TBARS)}

Approximately $2 \mathrm{~g}$ of meat sample was homogenized with $20 \mathrm{~mL} 0.1 \mathrm{M}$ phosphate buffer (pH 7.0) for $2 \mathrm{~min}$. An aliquot of homogenate $(1 \mathrm{~mL})$ was placed into a glass tube and added $50 \mu \mathrm{L}$ of butylated hydroxytoluene (BHT; $7.2 \%$ in ethanol) and $1.95 \mathrm{~mL}$ thiobarbituric acid (TBA)/trichloroacetic acid (TCA)/ $\mathrm{HCl}$ solution $(0.375 \% \mathrm{TBA}, 15 \% \mathrm{TCA}$ and $0.25 \mathrm{~N} \mathrm{HCl})$. The homogenate was incubated in a shaking water bath at $90^{\circ} \mathrm{C}$ for $15 \mathrm{~min}$. Then, the mixture was allowed to cool at room temperature followed by filtration with a filter paper. The supernatant was read at $531 \mathrm{~nm}$ with a UV-vis spectrophotometer (G1115AA, Agilant technologics, USA) against a blank containing $2 \mathrm{~mL}$ of TBA/TCA/HCl solution in $1 \mathrm{~mL}$ of distilled water. Thiobarbituric acid-reactive substances (TBARS) was calculated as milligram of malonaldehyde (MDA) per $\mathrm{kg}$ of sample, and compared with a standard curve constructed with1,1,3,3-tetramethoxyprophane.

\section{Statistical analysis}

Experimental data was analyzed by analysis of variance (ANOVA) procedure of statistical analysis systems (SAS, 2002). Duncan's multiple range test was used to determine significant differences among means at $5 \%$ level of significance (SAS, 2002). 


\section{Results and Discussion}

Effects of dry- and wet-aging on $\mathrm{pH}$ of shoulder blade and belly cuts are presented in Table 1. The $\mathrm{pH}$ was not significantly ( $>0.05$ ) varied till $14 \mathrm{~d}$ of aging. Among the wet-aged samples $\mathrm{pH}$ tended to be decreased with aging, whereas no major variations were observed among the dry-aged samples. At $21 \mathrm{~d}$ of aging, a significant variation was found between the dryaged (pH 5.91) and wet-aged ( $\mathrm{pH}$ 5.73) shoulder blade, and the lowest $\mathrm{pH}$ was found for wet-aged pork cuts. The reduction of $\mathrm{pH}$ in meat during aging could be due to an accumulation of lactic acid in the vacuum package originated from the growth of lactic acid bacteria (Blixt and Borch, 2002). The results of our study are in agreement with Lee et al. (2010) who reported that the aging method and time showed significant effect on the $\mathrm{pH}$ of meat, and a lower $\mathrm{pH}$ was observed for wet-aged pork meat as compared to dry-aged pork meat. Aksu et al. (2005) reported that the dry aging process lead to the formation of nitrogen compounds from proteins due to proteolysis resulting in an increase in the $\mathrm{pH}$.

The effects of dry- and wet-aging on WHC of pork cuts are shown in Table 1 . The WHC, RW \% by $2.5 \mathrm{~kg}$ pressure, was significantly $(\mathrm{p}<0.05)$ different between SW and SD, as well as BW and BD after 14 and $7 \mathrm{~d}$ of aging, respectively. All wetaged pork cuts showed higher RW \% than the dry-aged pork cuts, and the value of RW was increased for all samples (except $\mathrm{BD}$ ) till $14 \mathrm{~d}$ of aging. The range of initial RW \% was 1.81 (SD) to $2.46(\mathrm{BW})$, and the values were increased to 4.78 for SW, 2.76 for SD, and 3.53 for $\mathrm{BW}$, while RW \% decreased to 1.07 for $\mathrm{BD}$, at $14 \mathrm{~d}$. At the end of aging (day 21), RW \% of SW, SD and BW decreased again. Dry-aged pork cuts showed significantly lower RW \% when compared to the wet-aged pork cuts, which could be due to the methods related to wet aging (aged in a vacuum packet preventing surface drying) and dry aging (without protective packet leading to moisture evaporation from the surface). During postmortem aging, different biochemical changes such as proteolysis, protease-inhibitor activation, and the oxidation of proteins occurred. These may affect the degradation of myofibrillar proteins which is related to the WHC and meat tenderness (Huff-Lonergan and Lonergan, 2005). Smith et al. (2008) reported that dry-aged cuts loss more weight than wet-aged cuts owing to loss of water. Consequently, results suggest that wet-aged cuts lose less weight leading to juicy meat.

Table 2 shows the color measurements of pork cuts as influenced by different aging methods. The data show that different aging significantly effects the color measurements of pork cuts. The lightness ( $\left.\mathrm{L}^{*}\right)$ of wet-aged pork cuts was increased till 14 $\mathrm{d}$ of aging with values of 49.78 for SW and 58.30 for BW, while the $\mathrm{L}^{*}$ value of dry-aged cuts was 41.51 for SD and 52.42 for $\mathrm{BD}$. These results indicated that the wet-aged pork cuts had significantly higher $\mathrm{L}^{*}$ values as compared to the dry-aged cuts. By contrast, the value of redness $\left(\mathrm{a}^{*}\right)$ for wet-aged samples tended to decrease slightly till $14 \mathrm{~d}$ of aging and slightly increased for dry-aged samples. In case of yellowness $\left(b^{*}\right)$ the value was increased with aging time for all samples and the

Table 1. Changes in muscle $\mathrm{pH}$ and released water (RW) \% of wet- and dry-aged pork cuts during aging

\begin{tabular}{|c|c|c|c|c|c|c|c|c|}
\hline \multirow{2}{*}{$\begin{array}{l}\text { Pork } \\
\text { cuts }\end{array}$} & \multicolumn{4}{|c|}{$\mathrm{pH}$} & \multicolumn{4}{|c|}{ RW (\%) } \\
\hline & Day 1 & Day 7 & Day 14 & Day 21 & Day 1 & Day 7 & Day 14 & Day 21 \\
\hline SW & $5.94 \pm 0.09^{\mathrm{a}}$ & $5.89 \pm 0.19^{\mathrm{ab}}$ & $5.83 \pm 0.08^{\mathrm{ab}}$ & $5.73 \pm 0.04^{\mathrm{bB}}$ & $2.01 \pm 0.08^{\mathrm{d}}$ & $2.58 \pm 0.08^{\mathrm{c}}$ & $4.78 \pm 0.16^{\mathrm{aA}}$ & $4.08 \pm 0.20^{\mathrm{bA}}$ \\
\hline $\mathrm{SD}$ & $5.92 \pm 0.09$ & $5.94 \pm 0.11$ & $5.89 \pm 0.05$ & $5.91 \pm 0.01^{\mathrm{A}}$ & $1.81 \pm 0.20^{\mathrm{bc}}$ & $2.36 \pm 0.40^{\mathrm{ab}}$ & $2.76 \pm 0.17^{\mathrm{aB}}$ & $1.46 \pm 0.17^{\mathrm{cB}}$ \\
\hline BW & $5.84 \pm 0.03^{\mathrm{a}}$ & $5.83 \pm 0.01^{\mathrm{a}}$ & $5.79 \pm 0.07^{\mathrm{ab}}$ & $5.72 \pm 0.08^{b}$ & $2.46 \pm 0.23^{\mathrm{b}}$ & $3.95 \pm 0.57^{\mathrm{aA}}$ & $3.53 \pm 0.05^{\mathrm{abA}}$ & $2.22 \pm 0.26^{\mathrm{bA}}$ \\
\hline $\mathrm{BD}$ & $5.85 \pm 0.01$ & $5.82 \pm 0.07$ & $5.86 \pm 0.03$ & $5.80 \pm 0.05$ & $2.20 \pm 0.17^{\mathrm{a}}$ & $1.80 \pm 0.46^{\mathrm{abB}}$ & $1.07 \pm 0.27^{\mathrm{cB}}$ & $1.25 \pm 0.38^{\mathrm{bcB}}$ \\
\hline
\end{tabular}

All values are mean \pm standard deviation $(\mathrm{n}=5)$; Different superscripts in a column $\left({ }^{\mathrm{A}-\mathrm{B}}\right)$ and row ${ }^{\mathrm{a}-\mathrm{d}}$ ) indicate significant difference $(\mathrm{p}<0.05)$.

SW, shoulder blade-wet aging; SD, shoulder blade-dry aging; BW, belly-wet aging; BD, belly-dry aging. 
Table 2. Changes in color measurements of wet- and dry-aged pork cuts during aging

\begin{tabular}{|c|c|c|c|c|c|c|c|c|c|c|c|c|}
\hline \multirow{2}{*}{$\begin{array}{l}\text { Pork } \\
\text { cuts }\end{array}$} & \multicolumn{4}{|c|}{$\mathrm{L}^{*}$} & \multicolumn{4}{|c|}{$a^{*}$} & \multicolumn{4}{|c|}{$b^{*}$} \\
\hline & Day 1 & Day 7 & Day 14 & Day 21 & Day 1 & Day 7 & Day 14 & Day 21 & Day 1 & Day 7 & Day 14 & Day 21 \\
\hline SW & $\begin{array}{c}48.32 \\
\pm 1.56^{\mathrm{ab}}\end{array}$ & $\begin{array}{c}49.83 \\
\pm 0.32^{\mathrm{aA}}\end{array}$ & $\begin{array}{c}49.78 \\
\pm 0.42^{\mathrm{aA}}\end{array}$ & $\begin{array}{c}46.70 \\
\pm 1.63^{\mathrm{bA}}\end{array}$ & $\begin{array}{l}16.89 \\
\pm 0.99\end{array}$ & $\begin{array}{l}16.63 \\
\pm 1.02\end{array}$ & $\begin{array}{c}14.72 \\
\pm 1.80^{\mathrm{B}}\end{array}$ & $\begin{array}{c}14.84 \\
\pm 0.25^{\mathrm{B}}\end{array}$ & $\begin{array}{c}3.74 \\
\pm 0.66^{\mathrm{c}}\end{array}$ & $\begin{aligned} & 5.15 \\
\pm & 1.07^{\mathrm{bc}}\end{aligned}$ & $\begin{array}{c}6.04 \\
\pm 0.15^{\mathrm{ab}}\end{array}$ & $\begin{array}{c}6.40 \\
\pm 0.11^{\mathrm{a}}\end{array}$ \\
\hline SD & $\begin{array}{c}46.41 \\
\pm 1.20^{\mathrm{a}}\end{array}$ & $\begin{array}{c}43.76 \\
\pm 1.67^{\mathrm{abB}}\end{array}$ & $\begin{array}{c}41.51 \\
\pm 1.72^{\mathrm{bB}}\end{array}$ & $\begin{array}{c}42.49 \\
\pm 0.74^{\mathrm{bB}}\end{array}$ & $\begin{array}{l}16.43 \\
\pm 0.59\end{array}$ & $\begin{array}{l}17.47 \\
\pm 1.22\end{array}$ & $\begin{array}{c}17.44 \\
\pm 1.95^{\mathrm{A}}\end{array}$ & $\begin{array}{c}17.16 \\
\pm 2.17^{\mathrm{A}}\end{array}$ & $\begin{array}{c}3.35 \\
\pm 0.13^{\mathrm{c}}\end{array}$ & $\begin{array}{c}5.29 \\
\pm 0.46^{\mathrm{b}}\end{array}$ & $\begin{aligned} & 6.35 \\
\pm & 1.69^{\mathrm{ab}}\end{aligned}$ & $\begin{array}{c}7.70 \\
\pm 0.70^{\mathrm{a}}\end{array}$ \\
\hline BW & $\begin{array}{l}56.71 \\
\pm 1.39\end{array}$ & $\begin{array}{c}57.68 \\
\pm 1.58^{\mathrm{A}}\end{array}$ & $\begin{array}{c}58.30 \\
\pm 2.10^{\mathrm{A}}\end{array}$ & $\begin{array}{c}54.60 \\
\pm 2.20^{\mathrm{A}}\end{array}$ & $\begin{array}{l}11.26 \\
\pm 0.52\end{array}$ & $\begin{array}{l}12.03 \\
\pm 0.56\end{array}$ & $\begin{array}{l}12.11 \\
\pm 1.03\end{array}$ & $\begin{array}{l}12.72 \\
\pm 0.67\end{array}$ & $\begin{array}{c}4.58 \\
\pm 0.34^{\mathrm{c}}\end{array}$ & $\begin{array}{c}6.16 \\
\pm 0.29^{\mathrm{b}}\end{array}$ & $\begin{array}{c}6.85 \\
\pm 0.09^{\mathrm{a}}\end{array}$ & $\begin{aligned} & 6.60 \\
\pm & 0.64^{\mathrm{ab}}\end{aligned}$ \\
\hline $\mathrm{BD}$ & $\begin{array}{c}55.45 \\
\pm 0.30^{\mathrm{a}}\end{array}$ & $\begin{array}{c}53.39 \\
\pm 1.82^{\mathrm{abB}}\end{array}$ & $\begin{array}{c}52.42 \\
\pm 1.59^{\mathrm{bB}}\end{array}$ & $\begin{array}{c}50.69 \\
\pm 1.77^{\mathrm{bB}}\end{array}$ & $\begin{array}{l}11.66 \\
\pm 0.82\end{array}$ & $\begin{array}{l}12.86 \\
\pm 0.20\end{array}$ & $\begin{array}{l}12.75 \\
\pm 1.48\end{array}$ & $\begin{array}{l}13.89 \\
\pm 1.84\end{array}$ & $\begin{array}{c}4.45 \\
\pm 0.06^{\mathrm{c}}\end{array}$ & $\begin{array}{c}6.09 \\
\pm 0.40^{\mathrm{b}}\end{array}$ & $\begin{array}{c}6.69 \\
\pm 0.20^{\mathrm{ab}}\end{array}$ & $\begin{array}{c}7.11 \\
\pm 0.48^{\mathrm{a}}\end{array}$ \\
\hline
\end{tabular}

All values are mean \pm standard deviation $(\mathrm{n}=5)$; Different superscripts in a column $\left({ }^{\mathrm{A}-\mathrm{B}}\right)$ and row ${ }^{(\mathrm{a}-\mathrm{c}}$ ) indicate significant difference $(\mathrm{p}<0.05)$. SW, shoulder blade-wet aging; SD, shoulder blade-dry aging; BW, belly-wet aging; BD, belly-dry aging.

highest value was observed at the end of aging (21 days). The higher $\mathrm{L}^{*}$ values and lower a* values for wet-aged samples could be due to increased WHC. Kim et al. (2016) reported that the dry-aged beef loins were darker (lower L*values) than the wet-aged loins, because of the higher moisture content of wet-aged samples after aging resulting in increased light reflection. Our results clearly showed that the dry-aged pork cuts were darker (lower lightness and higher redness) than the wet-aged pork cuts.

There was no significant ( $>0.05$ ) variation between the WBSF value of pork cuts for 14 days of aging (Fig. 1). But the aging method showed significant interactions among the pork cuts at $21 \mathrm{~d}$, and the WBSF value decreased with aging for all samples. Among the samples, the highest WBSF value was found at day $1 \mathrm{for}$ SD and the value 0.76 was lowest at day 21 for BD. In comparison between aging methods, wet-aged pork cuts had a significantly higher WBSF value than the dry-aged pork cuts at 21 days of aging. This is presumably due to the storing without protective packing for dry-aging process resulting in increased oxidative deterioration and degradation of proteins leading to reduce the shear force of dry-aged pork cuts. In the case of wet-aging the plastic packing did not permit the loss of moisture and the meat held more moisture resulting in an

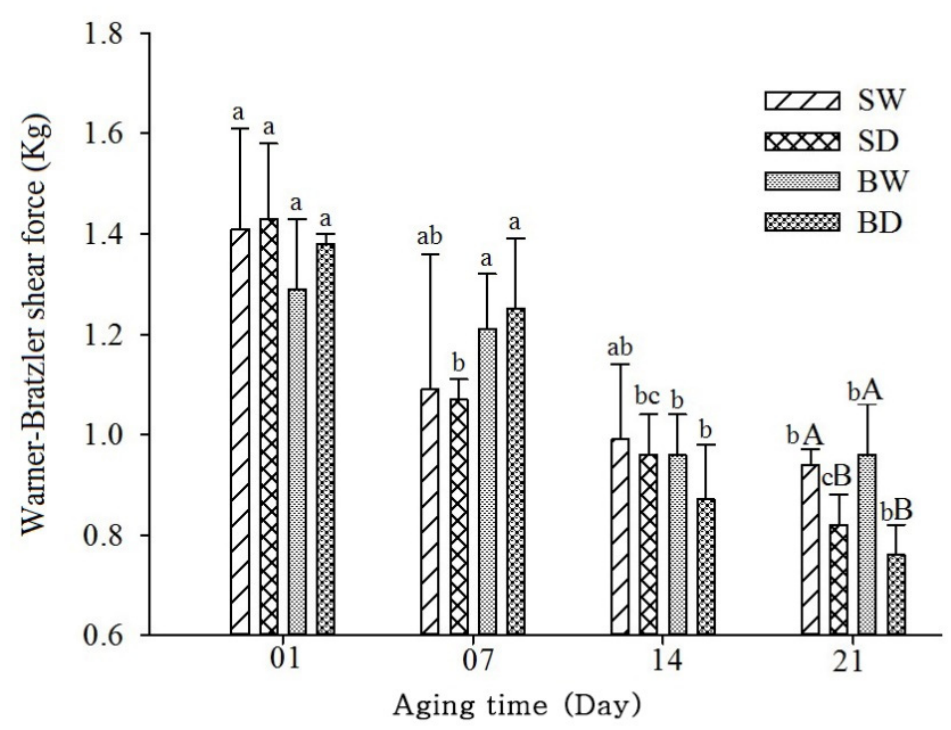

Fig. 1. Shear force of different meat cuts at different aging time. SW, shoulder cut wet-aging; SD, shoulder cut dry-aging; BW, belly cut wet-aging; BD, belly cut dry-aging; different letters in the bars indicate significant differences $(p<0.05)$ of shear force among the samples. 
increase in the tenderness and juiciness (Adegoke and Falade, 2005). It was reported that the WBSF values decreased with increasing the duration of aging (Davis et al., 2004; Obuz et al., 2014). Campbell et al. (2001) have indicated that dry aging reduced shear forces after 14 and 21 days. It was also reported that an increase in tenderness by aging beef in a refrigerator results in the breakdown of the Z-disk in the myofibril of muscles (Kim et al., 2007).

SDS-PAGE analysis provides information about structural characteristics of protein and its enzymatic degradation during aging, which is related to the tenderness, WHC and other meat quality characteristics (Liu et al., 2016; Marino et al., 2013). Changes in different proteins of pork shoulder blade during aging are depicted in Fig. 2 to indicate bands subjected to densitometric profile of proteins. The staining intensity of different bands for proteins was decreased with aging. Peptide bands for different proteins such as myosin heavy chain (MHC), C-protein, $\alpha$-actinin, desmin, actin, troponin-T/tropomyosin$\beta$, myosin light chain-1 (MLC-1), myosin light chain-2 (MLC-2) were identified at the molecular size range of between 21 and $205 \mathrm{kDa}$. The wet-aged cut meat showed $>12-14$ distinct bands at 7 and 14 days of aging (lanes 2 and 3), while at 21 days of aging the bands (lane 4) were relatively diffused. In case of dry-aged pork cut (lanes 5, 6 and 7), the band intensity was lower as compared to the wet-aged meat cut, and at 21 days of aging very diffuse or no bands appeared, particularly for C-protein, $\alpha$-actinin, desmin, MLC-1, MLC-2 indicating degradation of proteins. These results are in agreement with Marino et al. (2013) who reported the percentage of myofibrillar proteins and proteolytic products are affected by aging time. It has been shown that aging significantly affects MHC, MLC1 proteins and polypeptides from 170 to $138 \mathrm{kDa}$ and from 32 to 27 $\mathrm{kDa}$ (Marino et al., 2013). It was also reported that the disruption of actomyosin complex (MLC1 is associated with MHC

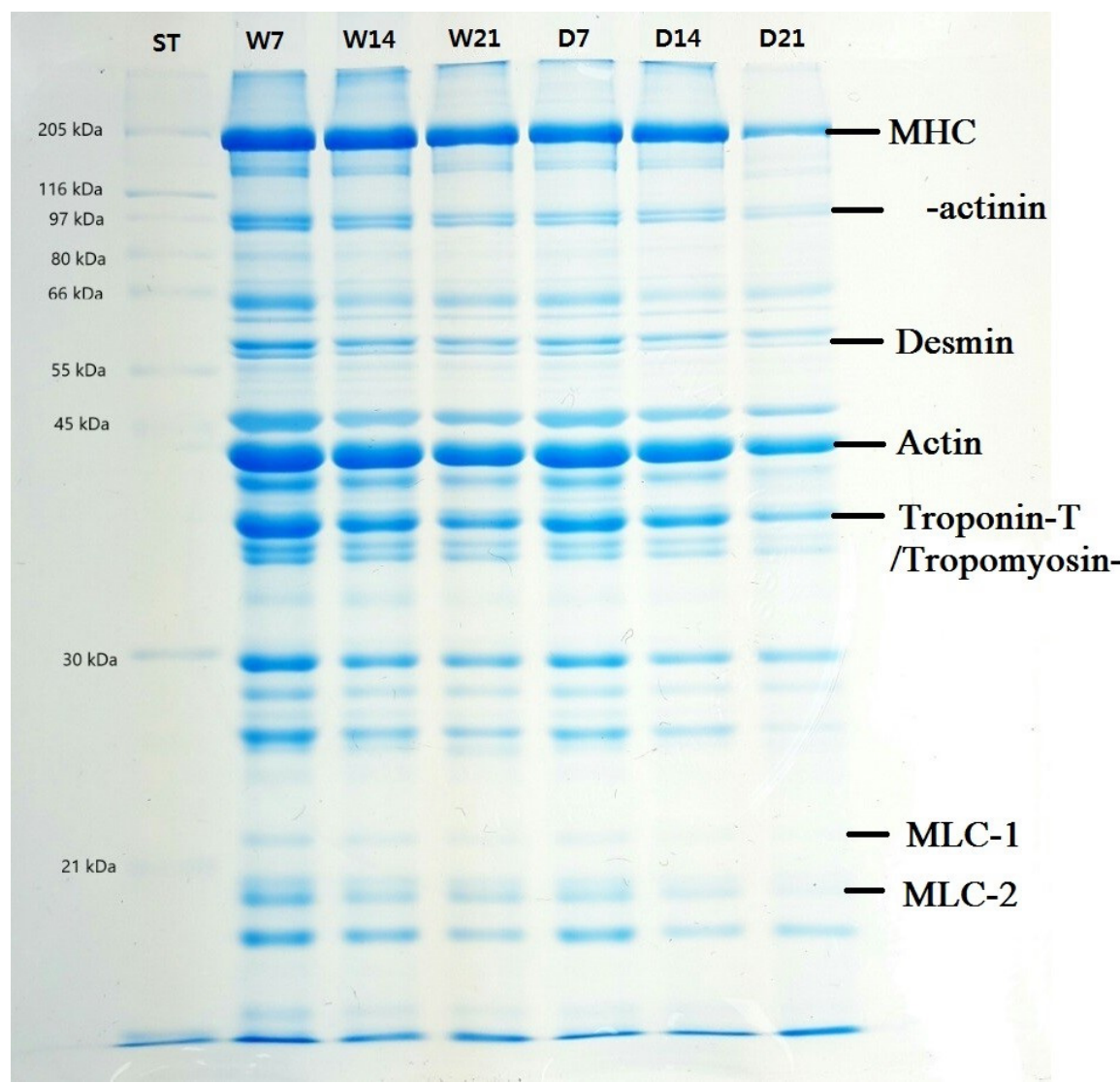

Fig. 2. Sodium dodecyl sulfate-polyacrylamide gel electrophoresis (SDS-PAGE) patterns of pork muscle. Lane-1, Molecular weight standard (M); Lane-2, 3 and 4 (W7, W14 and W21), wet-aged pork cut at day 7, 14 and 21, respectively; Lane-5, 6, and 7 (D7, D14 and D21), Dry-aged pork cut at day 7, 14 and 21, respectively. 
and actin) is directly related with meat tenderness during aging (Taylor et al., 1995), and degradation of desmin protein lead to drip loss during postmortem storage (Zhang et al., 2006). Our results also clearly showed that proteolysis is the major factor related to variation in pork quality and more affected by dry-aging compared to wet-aging.

The production of TBARS in different pork cuts during aging was measured as an indication of lipid oxidation (Fig. 3). It is very natural for increasing lipid oxidation with aging, and in our study the oxidation rate for different pork cuts was different. Among the pork cuts the TBARS values were in the range of 0.08 to 0.53 , while SW and BD had the lowest value at day 1 , and the highest value was only for BD at day 21 . The results indicated that dry-aged samples had a faster rate of oxidation than the wet-aged samples. Among the samples, the pork belly had more increased oxidation than the shoulder blade. The higher oxidation rate may be related to a higher level of fat and interaction with oxygen. In the case of dry-aged samples the aging carried out without protective packing resulted in more interaction with oxygen leading to a higher rate of oxidation. By contrast, protective packing for wet-aging may led to lower oxidation. It was reported that the higher fat levels, interaction with oxygen, temperature etc. lead to oxidative deterioration more rapidly (Pogorzelska et al., 2018). Kim et al. (2017) reported that the conventional carcass dry-aging influenced the oxidation of beef loins (due to no packaging materials are used during aging) more than the wet-aging. The rapid oxidation in dry-aged meat compared to wet-aged meat was also confirmed in the present study.

\section{Conclusion}

Meat quality traits of wet-aging and dry-aging pork cuts change differently. Wet-aging led to increase RW \%, WBSF values and lightness $\left(\mathrm{L}^{*}\right)$. By contrast, the dry-aging cuts had significantly $(\mathrm{p}<0.05)$ higher redness $\left(\mathrm{a}^{*}\right)$ and lipid oxidation (TBARS) owing to unprotected storing during aging. SDS-PAGE analysis showed that dry-aged pork cuts had relatively lower intensity of protein bands indicating more severe degradation of meat proteins than wet-aged pork cuts. Therefore, dryaged pork cuts should be treated differently during retail distribution.

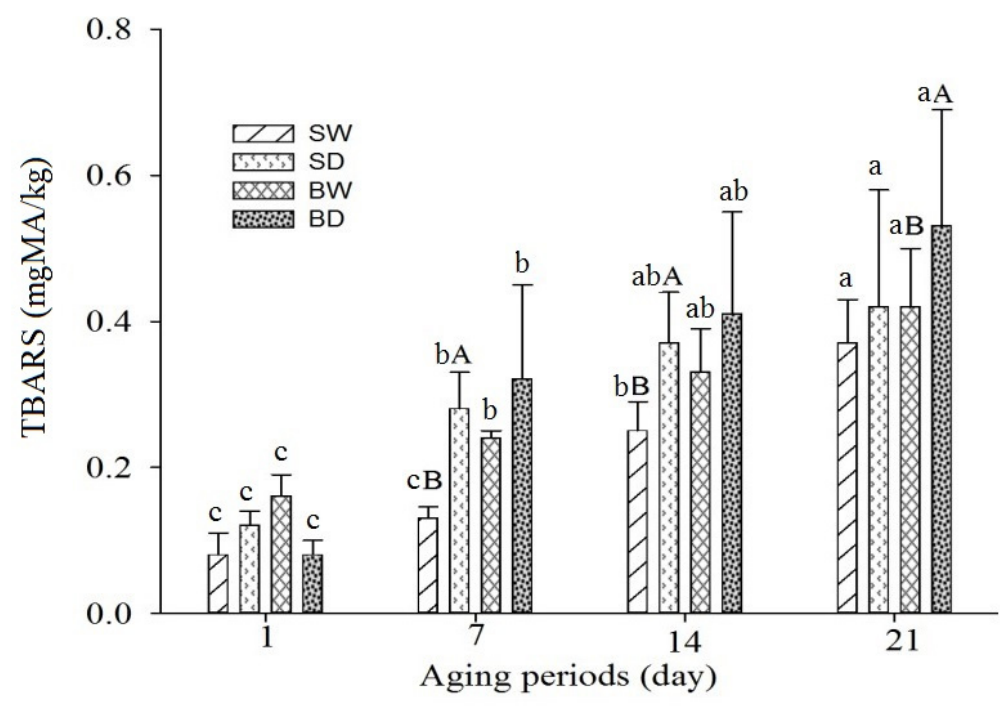

Fig. 3. Thiobarbituric acid-reactive substances (TBARS) in different pork cuts during aging. Different letters in bars among the samples in a particular aging day indicate significant differences $(p<0.05)$. 


\section{References}

Adegoke GO, Falade KO. 2005. Quality of meat. J Food Agric Environ 3:87-90.

Aksu MI, Kaya M, Ockerman HW. 2005. Effect of modified atmosphere packaging and temperature on the shelf life of sliced pastirma produced from frozen/thawed meat. J Muscle Foods 16:192-206.

Blixt Y, Borch E. 2002. Comparison of shelf life of vacuum-packed pork and beef. Meat Sci 60:371-378.

Campbell RE, Hunt MC, Levis P, Chambers IV E. 2001. Dry-aging affects on palatability of beef longissimus muscle. J Food Sci 66:196-199.

Davis KJ, Sebranek JG, Huff-Lonergan E, Lonergan SM. 2004. The effects of aging on moisture-enhanced pork loins. Meat Sci 66:519-524.

Dikeman ME, Obuz E, Gök V, Akkaya L, Stroda S. 2013. Effects of dry, vacuum, and special bag aging: USDA quality grade; and end-point temperature on yields and eating quality of beef longissimus lumborum steaks. Meat Sci 94:228-233.

Huff-Lonergan E, Lonergan SM. 2005. Mechanisms of water-holding capacity of meat: The role of postmortem biochemical and structural changes. Meat Sci 71:194-204.

Joo ST. 2018. Determination of water-holding capacity of porcine musculature based on released water method using optimal load. Korean J Food Sci An 38:823-828.

Joo ST, Kim GD, Hwang YH, Ryu YC. 2013. Control of fresh meat quality through manipulation of muscle fiber characteristics. Meat Sci 95:828-836.

Kim JH, Cho SH, Seong PN, Hah KH, Kim HK, Park BY, Lee JM, Kim DH, Ahn CN. 2007. Effect of ageing temperature and time on the meat quality of longissimus muscle from Hanwoo steer. Korean J Food Sci An 27:171-178.

Kim YHB, Kemp R, Samuelsson LM. 2016. Effects of dry-aging on meat quality attributes and metabolite profiles of beef loins. Meat Sci 111:168-176.

Kim YHB, Meyers B, Kim HW, Liceaga AM, Lemenager RP. 2017. Effects of stepwise dry/wet-aging and freezing on meat quality of beef loins. Meat Sci 123:57-63.

Laemmli UK. 1970. Cleavage of structural proteins during the assembly of the head of bacteriophage T4. Nature 227:680685.

Laster MA, Smith RD, Nicholson KL, Nicholson JDW, Miller RK, Griffin DB, Harris KB, Savell JW. 2008. Dry versus wet aging of beef: Retail cutting yields and consumer sensory attribute evaluations of steaks from ribeyes, strip loins, and top sirloins from two quality grade groups. Meat Sci 80:795-804.

Lee YJ, Kim CJ, Park BY, Seong PN, Kim JH, Kang GH, Kim DH, Cho SH. 2010. Chemical composition, cholesterol, transfatty acids contents, $\mathrm{pH}$, meat color, water holding capacity and cooking loss of Hanwoo beef (Korean native cattle) quality grade. Korean J Food Sci An 30:997-1006.

Liu J, Arner A, Puolanne E, Ertbjerg P. 2016. On the water-holding of myofibrils: Effect of sarcoplasmic protein denaturation. Meat Sci 119:32-40.

Marino R, Albenzio M, Della Malva A, Santillo A, Loizzo P, Sevi A. 2013. Proteolytic pattern of myofibrillar protein and meat tenderness as affected by breed and aging time. Meat Sci 95:281-287.

Obuz E, Akkaya L, Gök V, Dikeman ME. 2014. Effects of blade tenderization, aging method and aging time on meat quality characteristics of Longissimus lumborum steaks from cull Holstein cows. Meat Sci 96:1227-1232.

Pogorzelska E, Godziszewska J, Brodowska M, Wierzbicka A. 2018. Antioxidant potential of Haematococcus pluvialis 
extract rich in astaxanthin on colour and oxidative stability of raw ground pork meat during refrigerated storage. Meat Sci 135:54-61.

Smith RD, Nicholson KL, Nicholson JDW, Harris KB, Miller RK, Griffin DB, Savell JW. 2008. Dry versus wet aging of beef: Retail cutting yields and consumer palatability evaluations of steaks from US Choice and US Select short loins. Meat Sci 79:631-639.

Stenström H, Li X, Hunt MC, Lundström K. 2014. Consumer preference and effect of correct or misleading information after ageing beef longissimus muscle using vacuum, dry ageing, or a dry ageing bag. Meat Sci 96:661-666.

Taylor RG, Geesink GH, Thompson VF, Koohmaraie M, Goll DE. 1995. Is Z-disk degradation responsible for postmortem tenderization. J Anim Sci 73:1351-1367.

Zhang WG, Lonergan SM, Gardner MA, Huff-Lonergan E. 2006. Contribution of postmortem changes of integrin, desmin and $\mu$-calpain to variation in water holding capacity of pork. Meat Sci 74:578-585. 